Acta vet. scand. 1967, 8, 211-216.

From the State Veterinary Serum Laboratory, Copenhagen, Denmark.

\title{
DÖHLE BODIES IN NEUTROPHILS OF A HORSE
}

By

\author{
N. F. Friis and J. Bech
}

Döhle bodies are small basophilic granules which may sometimes be observed in the cytoplasm of neutrophils of man and certain animal species as an expression of a toxemic effect of certain disease conditions. Usually they are round or oval and may be seen by ordinary light microscopy, ranging in size from just visible to $1-2 \mu$. They seem to develop by incomplete utilization of RNA during maturation processes of the cytoplasm. Their significance is unknown (Sandoz 1952, Wintrobe 1961, Schalm 1965a).

In 1912 Döhle saw and described these bodies in neutrophils from human patients suffering from scarlet fever and cancer. Later they have been observed in man during the acute course of several infectious diseases (Oski et al. 1962), in May-Hegglin's anomaly (Leitner et al. 1954), in patients with burns (Weiner \& Topley 1955), and after chemotherapeutic treatment of cancer with cyclophosphamide (Itoga \& Laszlo 1962), and also in cases of normal pregnancy (Abernathy 1966).

In animal species, except for the cat, presence of Döhle bodies seems to be a fairly rare phenomenon. Ackart et al. (1940) have reported the existence of such bodies in $3-80 \%$ of the neutrophils in normal cats. According to Schalm \& Smith (1963) they occur in neutrophils of this species in toxemic diseases. Occurrence of Döhle bodies in the neutrophils of anemic pigs has been reported by överås (1963).

As Döhle bodies have, apparently, never been described in horses, it has been deemed of interest here to report the finding of such bodies in a horse. 


\section{OBSERVATIONS}

\section{Clinical findings}

The horse concerned was an eight-year-old thoroughbred mare, which had been imported from England in November 1965. On arrival she was suffering from an acute attack of fever, which disappeared after treatment with antibiotics. During the year 1966, however, several attacks of fever occurred at intervals of 2-3 months. During these relapses a marked anemia was present, in one instance followed by jaundice. A pleurisy was diagnosed, and the horse became emaciated in spite of a good appetite during the intervals between the acute attacks. During a relapse in December 1966, blood samples were drawn by the local practitioner and sent to the laboratory for hematologic examination. The horse died a few days later, and at autopsy a severe pleurisy was found $(20 \mathrm{l}$ of reddish, turbid fluid in the pleural cavity, and a $3 \mathrm{~cm}$ thick red deposit of granulation tissue covering the parietal pleura) together with a marked induration of the liver and the kidneys.

\section{Hematologic examination}

Two EDTA-stabilized blood samples drawn at an interval of 4 days were sent in for hematologic examination. Blood smears were prepared immediately after venipuncture. The hematologic data have been set out in Table 1 .

\section{Interpretation of the hemogram}

Erythrocytes: The values are below the average of thoroughbreds, but still within the normal range.

Leukocytes: A marked change of the white blood pattern was observed from the first to the second investigation. Thus, a marked increase of the number of neutrophils was seen, whereas the number of lymphocytes and monocytes remained in a relatively low, but normal range. Eosinophils were totally absent. In both samples there were an increased number of neutrophils of immature morphology. The cell pattern fits well into the observed course of disease and post-mortem findings, i.e. that the horse was in an acute phase of a severe disease condition. 
T a b l e 1. Results of hematologic examination.

\begin{tabular}{|c|c|c|}
\hline Erythrocytes: & $15 / 121966$ & $19 / 121966$ \\
\hline $\mathrm{RBC} / \mathrm{mm}^{3}$ & $8.22 \times 10^{6}$ & $7.73 \times 10^{6}$ \\
\hline Hemoglobin & $11.1 \mathrm{~g} / 100 \mathrm{ml}$ & $10.5 \mathrm{~g} / 100 \mathrm{ml}$ \\
\hline PCV & 34.0 & 31.0 \\
\hline MCV & 41.4 & 40.1 \\
\hline MCH & 13.5 & 13.6 \\
\hline MCHC & 32.6 & 33.9 \\
\hline Anisocytosis & slight & slight \\
\hline Leukocytes: & $\%$ & $\%$ \\
\hline $\mathrm{WBC} / \mathrm{mm}^{3}$ & 5,400 & 31,500 \\
\hline Lymphocytes & $1,377(25.5)$ & $1,890(6.0)$ \\
\hline Monocytes & $108(2.0)$ & $158(0.5)$ \\
\hline Metamyelocytes & $135(2.5)$ & $630(2.0)$ \\
\hline Band neutrophils & $1,998(37.0)$ & $4,410(14.0)$ \\
\hline Segm. neutrophils & 1,782 & $24,412 \quad(77.5)$ \\
\hline Eosinophils & $0(0.0)$ & $0(0.0)$ \\
\hline Basophils & $0(0.0)$ & $0(0.0)$ \\
\hline \multicolumn{3}{|l|}{ Other tests: } \\
\hline Formol gel & not tested & +20 min. \\
\hline
\end{tabular}

Microscopic examination of May-Grünwald-Giemsa-stained smears

Apart from a slight anisocytosis of the erythrocytes there were no signs of anemia.

Neutrophils: As demonstrated in the hemogram a moderate shift to the left was noticed. Although many of the neutrophils were classified as segmented, they were not quite mature, as only two lobules were seen per nucleus. The structure and colour of the cytoplasm appeared to be fairly normal. In the cytoplasm some blue bodies were situated preferably in the periphery of the cell and evidently without connection to the nucleus. They were $1-3 \mu$ long, and most of them oval or rodlike of shape. Their borders appeared rather distinct and they had no internal structure. By staining with May-Grünwald-Giemsa they appeared blue without the reddish tinge which is characteristic of nuclear chromatin.

The percentage of neutrophils containing these bodies and the varying numbers per cell can be seen from Table 2 . The bodies were numerous in the first blood sample and rare in the next one, which was drawn 4 days later. 
T a b l e 2. Number of bodies in the different types of neutrophils per $\mathrm{mm}^{3}$ (and \%).

\begin{tabular}{llcrl}
\hline Date & Cell type & No bodies & $1-3$ bodies & $\begin{array}{l}4 \text { or } \\
\text { more bodies }\end{array}$ \\
\hline $15 / 12$ & $\begin{array}{c}\text { Band neutr. } \\
1,998 / \mathrm{mm}^{3} \\
\text { Segm. neutr. } \\
1,782 / \mathrm{mm}^{3}\end{array}$ & $360(18 \%)$ & $1,159(58 \%)$ & $479(24 \%)$ \\
$19 / 12$ & $\begin{array}{c}\text { Band neutr. } \\
4,410 / \mathrm{mm}^{3}\end{array}$ & $4,388(99.5 \%)$ & $22(0.5 \%)$ & $0(0 \%)$ \\
$\begin{array}{c}\text { Segm. neutr. } \\
24,412 / \mathrm{mm}^{3}\end{array}$ & $23,924(98.0 \%)$ & $488(2 \%)$ & $0(0 \%)$ \\
\hline
\end{tabular}

Except for the neutrophils, the white blood cells were morphologically normal.

\section{DISCUSSION}

The bodies demonstrated in the neutrophils of blood from the diseased horse fit well, regarding their localization, morphology, and staining property, to the criteria of the bodies described by Döhle (1912). Also the presence of these bodies during an acute phase of a serious disease seems to justify the diagnosis: Döhle bodies.

Unfortunately, a demonstration of the causative agent was impossible owing to difficulties in getting sufficient pathologic material. Most likely the disease was of bacterial etiology.

For further orientation blood smears from 50 horses, some normal and others suffering from various diseases, were examined for the presence of similar elements; but no bodies like the ones described above could be found.

Bluish staining of the cytoplasm and bluish cytoplasmic structures may sometimes be observed in the neutrophils. Such changes have, however, nothing to do with the Döhle bodies. For example, neutrophils with a bluish coloured cytoplasm are seen in diseases associated with toxic conditions, i.e., the so-called "toxic neutrophils" (Schalm 1965b). Among the 50 blood smears mentioned above, bluish cytoplasm was found in a few.

Basophilic substances in the cytoplasm have also been seen in horse neutrophils under other circumstances; e.g., Schulze 
(1956) found blue fluffs in the cytoplasm of band neutrophils and regarded them as a sign of immaturity. Another phenomenon is described by Schalm (1965c), namely the presence of bluishgray cytoplasmic inclusions, the appearance of which could apparently be induced by transmission of material from animal to animal.

\section{REFERENCES}

Abernathy, M. R.: Döhle bodies associated with uncomplicated pregnancy. Blood 1966, 27, 380-385.

Ackart, R. J., J. S. Shaw jr. \& J. S. Lawrence: The blood cell picture of normal cats. Anat. Rec. 1940, 76, 357-363.

Döhle, V.: Leukocyteneinschlüsse bei Scharlach. Zbl. Bakt., I. Abt. Orig. $1912,61,63-68$.

Itoga, T. \& J. Laszlo: Döhle bodies and other granulocytic alterations during chemotherapy with cyclophosphamide. Blood 1962, 20, $668-674$.

Leitner, S. J., E. Neumark \& P. A. Heeres: Panmyelopathy with Döhle bodies, thrombocytopenia and erythroblastosis (Hegglins Syndrome). Acta haemat. (Basel) 1954, 11, 321-327.

Oski, F. A., J. L. Naiman, D. M. Allan \& L. K. Diamond: Leukocytic inclusions - Döhle bodies - associated with platelet abnormality (The May-Hegglin Anomaly). Blood 1962, 20, 657-667.

Sandoz AG, Basel: Sandoz atlas of haematology. Basel, Sandoz 1952.

Schalm, O. W.: Veterinary hematology, Lea \& Febiger, Philadelphia 1965, 2nd ed., 133-134 (a), 184 (b), 462-464 (c).

Schalm, O. W. \& R. Smith: Some unique aspects of feline hematology in disease. Small Animal Clin. 1963, 3, 311-322.

Schulze, J.: Zur Definition der Stabkernigen beim Pferde. Mh. Vet.Med. 1956, 11, 203-205.

Weiner, W. \& E. Topley: Doehle bodies in the leukocytes of patients with burns. J. clin. Path. 1955, 8, 324-328.

Wintrobe, M. M.: Clinical hematology, Lea \& Febiger, Philadelphia 1961, 4th ed., 225.

överås, J.: Döhle bodies in neutrophil leukocytes of anaemic swine. Acta vet. scand. 1963, 4, 247-252.

\section{SLMMARY}

Döhle bodies were observed in a horse suffering from a chronic pleurisy. The bodies were demonstrated in about $80 \%$ of the neutrophils in blood smears prepared during an acute flare-up of the disease. One to 4 bodies were found in each cell, situated in the periphery of the cytoplasm. The size of the bodies was $1-3 \mu$ and the shape rodlike or oval. They stained blue with M-G-G. 
Blood smears were examined from 50 horses suffering from various diseases, but Döhle bodies could not be demonstrated in any of these cases.

\section{ZUSAMMENFASSUNG}

Döhle-Körperchen in neutrophilen Granulozyten bei einem Pferd.

Döhle-Körperchen wurden bei einem Pferd mit chronischer Pleuritis beobachtet. Sie wurden in etwa $80 \%$ der neutrophilen Granulozyten während einer akuten Phase der Krankheit nachgewiesen. 1 bis 4 Körperchen wurden in jeder Zelle in den peripheren Teilen des Zytoplasmas gefunden. Die Grösse war $1-3 \mu$ und die Form stabähnlich oder oval. Mit M-G-G wurden sie blau gefärbt.

Blutausstriche von 50 Pferden mit verschiedenen Krankheiten wurden untersucht. Döhle-Körperchen waren aber nicht nachweisbar.

\section{SAMMENDRAG}

Döhle-legemer i neutrophile granulocyter hos en hest.

Döhle-legemer blev fundet hos en hest lidende af en kronisk pleuritis. De blev påvist i ca. $80 \%$ af de neutrophile granulocyter under en akut fase af sygdommen. I hver celle fandtes fra 1 til 4 legemer placeret perifert $i$ cytoplasmaet. Størrelsen var $1-3, \mu$ og formen aflang (stavformet eller oval). De farvedes blå med M-G-G.

Blodudstrygningspræparater fra 50 heste lidende af forskellige sygdomme blev unders $\varnothing$ gt, men hos disse kunne Döhle-legemer ikke påvises.

(Received February 24, 1967). 

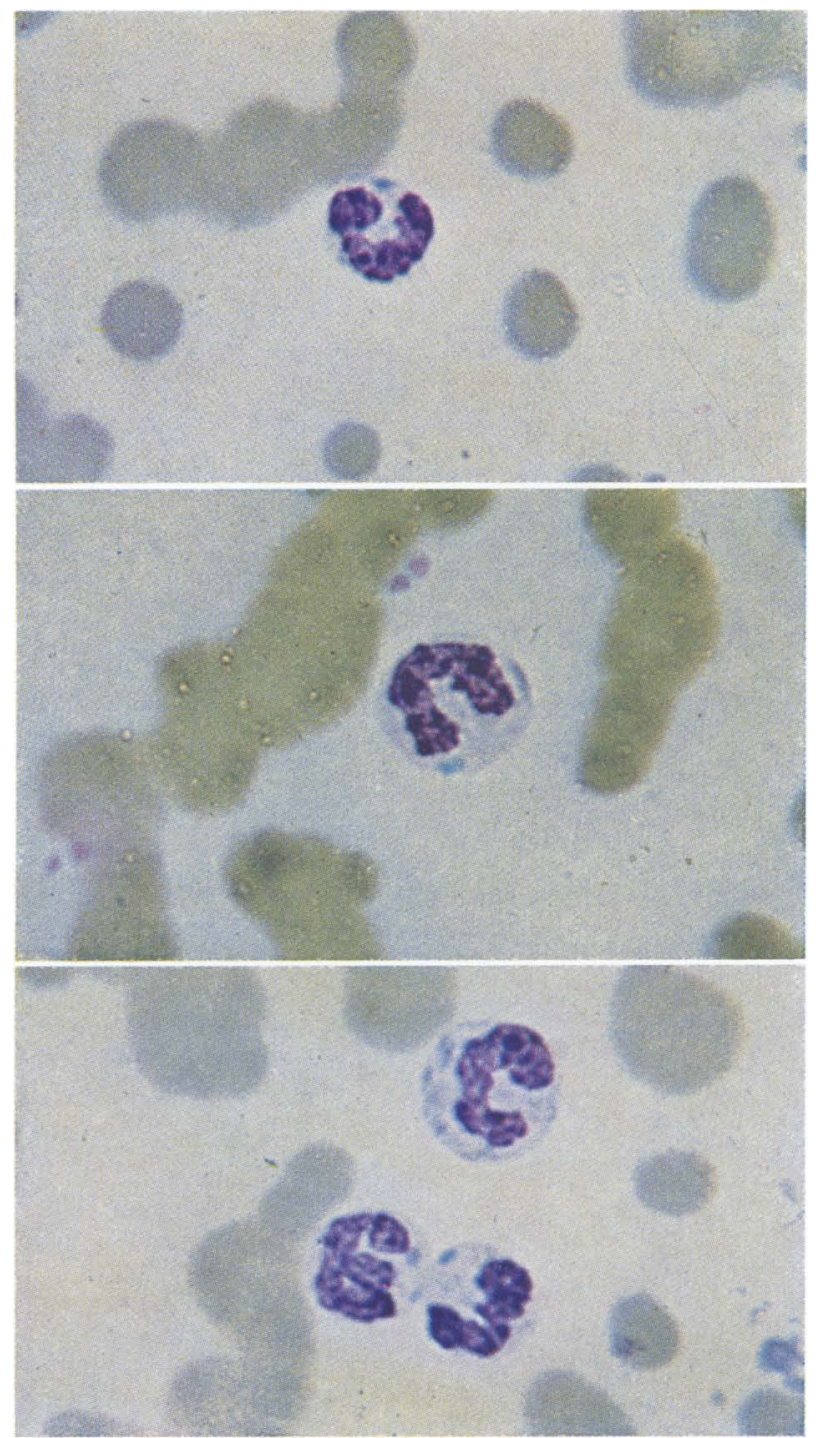

F i g u r e $1-3$. Blood smear of horse ( $q, 8$ years old). 1-4 Döhle bodies are seen in the cytoplasm of each neutrophil. They appear as small blue bodies $1-3 \mu$ long.

Stain: May-Grünwald-Giemsa.

Magnification: Ca. $1200 \times$. 